\title{
Distribution of Mercury in a Gadoid Fish Species, Tusk (Brosme brosme), and Its Implication for Food Safety
}

\author{
Kristine Kvangarsnes ${ }^{1,2}$, Sylvia Frantzen ${ }^{1}$, Kåre Julshamn ${ }^{1}$, Leif J. Sæthre ${ }^{2}$, Kjell Nedreaas ${ }^{3}$ and Amund Maage ${ }^{1}$ \\ 1. National Institute of Nutrition and Seafood Research, P.O. Box, Bergen 5817, Norway \\ 2. Department of Chemistry, University of Bergen, Alleg, Bergen 5007, Norway \\ 3. Institute of Marine Research, Postboks 1870 Nordnes, Bergen 5007, Bergen
}

Received: August 14, 2012 / Published: November 20, 2012.

\begin{abstract}
The tusk (Brosme brosme) is a popular gadoid fish for human consumption, which also is susceptible to mercury accumulation. However, few data of mercury levels in tusk exist, and it is difficult to compare tusk fished from assumed contaminated areas with background levels. The aim of this study was to increase the information of mercury levels observed in tusk from the Northeast Atlantic Ocean. Samples of tusk were collected from seven different localities in open ocean areas, nine along the Norwegian coastal current (NCC), and from two fjord stations. Determinations of mercury in muscle and liver were carried out using inductive coupled plasma mass spectrometry (ICPMS) after microwave-assisted wet digestion. The highest concentrations of mercury in muscle were found in tusk captured from the fjords Hardangerfjord and Sørfjord, and had mean concentrations of mercury at 1.5 and $1.7 \mathrm{mg}$ $\mathrm{kg}^{-1}$ wet weight (ww), respectively, where all of the tusk exceeded EU's upper limit of $0.5 \mathrm{mg} \mathrm{kg}^{-1} \mathrm{ww}$. The lowest concentrations of mercury were observed in tusk captured from the open ocean areas, and the concentrations ranged from 0.08 to $0.30 \mathrm{mg} \mathrm{kg}^{-1} \mathrm{ww}$. Mercury concentrations of tusk captured along the NCC ranged from 0.21 to $0.49 \mathrm{mg} \mathrm{kg}^{-1} \mathrm{ww}$. Mercury concentrations increased with the weight of the tusk, and variance analysis (ANOVA) of weight normalized mercury concentrations showed that there were significant differences in mercury concentrations between tusk collected from the open ocean, NCC and fjords, which indicates that differences in mercury concentration between different areas arecaused by other factors.
\end{abstract}

Key words: Tusk, mercury, food safety, U-864, ICPMS.

\section{Introduction}

The tusk (Brosme brosme) is a benthic gadoid fish species that can be found at depths from 100 to $1,000 \mathrm{~m}$ [1]. The tusk has its area of distribution along the Norwegian coast, in Norwegian fjords, and also in open ocean areas from the Western Barents Sea in the North to Skagerrak in the South and Iceland and Greenland in the West. In the Northeastern Atlantic, most of the tusk can be found between 150 and $450 \mathrm{~m}$ depths, and their diet consists mainly of fish and crustaceans [2]. While adult tusk usually inhabit relatively deep waters, younger individuals can be found at shallower depths. Of a total of about 590,000 tons of gadoid fish captured

Corresponding author: Amund Maage, professor, research field: contaminants in seafood. E-mail: amund.maage@nifes.no. in Norwegian fisheries in 2009, about 14,000 tons were tusk [3]. However, although tusk is not an important species in terms of volume, it is a popular fish for the restaurant market, with its fine taste and texture.

In human nutrition, fish is an important source of energy, important vitamins, proteins, selenium, iodine and fatty acids [4, 5], and in many countries, governments advise the population to increase the seafood intake. But fish is also known to contain undesirable substances, including mercury [4-7]. Mercury is an environmental pollutant that can be found in different forms: elementary (metallic) mercury, inorganic salts and organic mercury. The toxicity is dependent on the chemical form of the compound, where the organic form methyl mercury $\left(\mathrm{CH}_{3} \mathrm{Hg}^{+}\right)$is the most toxic. The main toxic effects of the methyl 
mercury to humans are effects in the central nervous system [8]. In fish muscle, methyl mercury is the dominant form of mercury [9], and fish consumption is the largest known source for human exposure to methyl mercury [10-12]. Due to its high affinity for sulfur, mercury can bind to the sulfur-containing amino acid cystein in proteins, and is distributed throughout the whole muscle tissue of the fish [13].

To protect human health from too high methyl mercury exposure, a provisional tolerable weekly dietary intake (PTWI) of mercury has been established. In 2003, the Joint FAO/WHO Expert Committee on Food Additives (JECFA) reduced the PTWI of mercury from 3.3 to $1.6 \mu \mathrm{g} \mathrm{kg}^{-1}$ body weight/week [14]. The PTWI has been set to protect the consumer groups most vulnerable to the toxic effects of methyl mercury, i.e., fetuses and young children whose brain development can be affected. For more practical use in health protection, the European Union (EU) has established upper regulatory limits for mercury in muscle tissue of fish for human consumption. For most fish, including tusk, this upper limit is set to $0.5 \mathrm{mg} \mathrm{kg}^{-1}$ wet weight ( $\mathrm{ww}$ ) while some species have been granted a higher limit of $1.0 \mathrm{mg} \mathrm{kg}^{-1} \mathrm{ww}$ [15].

In 2003, the wreck of a German submarine (U-864), sunken during World War II, was observed at a depth of $150 \mathrm{~m}$ about $2 \mathrm{~km}$ west of the island Fedje on the west coast of Norway [16]. The submarine was transporting iron bottles filled with up to 65 tons of metallic mercury intended for war use in Japan. It has been found that some of this mercury has leaked out into the sediments in the area around the wreck [17]. Following the finding of U-864, a monitoring program for seafood safety was established in the area, and at the depth where the submarine was found, tusk is the major fish species captured and analyzed. During the past years, a lot of information on the concentrations of mercury in tusk collected in the area around the wreck has therefore been developed [16]. However, apart from some unrefereed data (www.nifes.no/seafooddata; Berge et al. [18]), little information exists regarding normal range concentrations of mercury in tusk from other areas in the Northeast Atlantic. The very scarce data that do exist indicate that tusks captured near U-864 do not have higher concentrations of mercury than those captured in other areas, and it has not so far been possible to conclude whether or not the mercury concentration in fish captured near the wreck really is higher than "normal".

The aim of this study has been to study the concentrations of mercury in tusk captured in Norwegian waters, and to compare the mercury concentrations from coastal and open ocean areas with each other and with levels found near the sunken mercury-carrying submarine U-864.

\section{Materials and Methods}

\subsection{Sampling}

A total of 164 samples of tusk were collected at seven open ocean localities (Fig. 1a), while 133 samples were collected at five localities in the Norwegian coastal current (NCC), 36 samples at two localities within a fjord system and 75 samples at three localities near U-864 (Fig. 1b). Samples of tusk from the open ocean sites were collected during 2008 by research vessels from the Institute of Marine Research, using long lines. Sampling was done during different times of the year: Atlantic Ocean (AO), March and July; North Sea (NS), September; Norwegian Sea (NW); May and September and Barents Sea (BS), June and October. Along the NCC, samples of tusk were collected by local fishermen using long lines. Fish from the Skagerrak coast were caught in December 2008, while fish from the other localities were caught during 2009: Breisundet, April-May; Sotra, October and Florø and Karmøy, November. Fish from two positions inside Hardangerfjord and Sørfjord (Fig. 1b) were sampled in the same way. The tusk from Sørfjord were caught in October 2008, while the tusk from the Hardangerfjord were sampled in December 2009.

As a part of the seafood safety monitoring around U-864, in 2009, a total of 75 samples of tusk were 


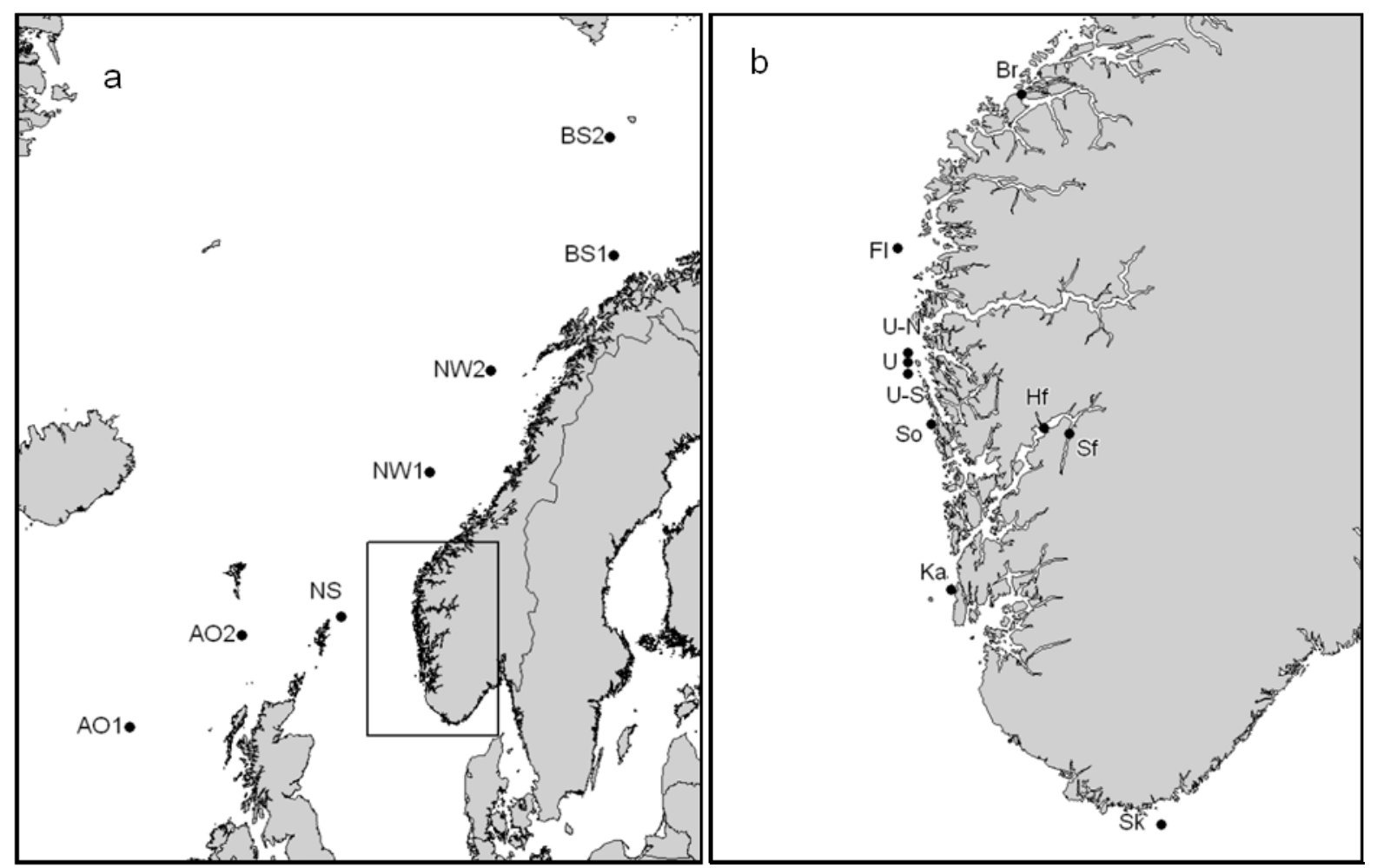

Fig. 1 Stations where tusk (Brosme brosme) were sampled for the analysis of mercury, (a) The open ocean positions: AO: Atlantic Ocean, NS: North Sea; NW: Norwegian Sea; BS: Barents Sea; (b) The coastal and fjord stations: Sk: Skagerrak coast, Ka: Karmøy; So: Sotra; Fl: Florø; Br: Breisundet; U: U-864; U-S: 4 nautical miles (nm) south of U-864: U-N; 4 nm north of U-864; Hf: Inner Hardangerfjord; Sf: Sørfjord.

collected near the position of the wreck and approximately $4 \mathrm{~nm}$ South and North of the wreck, respectively (Fig. 1b). This sampling was done by a local fisherman using special fish pots. The fish from the locality nearest U-864 and $4 \mathrm{~nm}$ to the north were caught in July, while the sampling $4 \mathrm{~nm}$ to the South was done in October-November. This work is also presented in a separate report [16].

The collected tusk was stored frozen $\left(<-20^{\circ} \mathrm{C}\right)$ until they were prepared for analysis. Prior to the analysis, the tusk was thawed, and the weight and length of each individual was determined. Otoliths were removed and later used for age determination. Each individual fish was filleted and skinned, and the whole fillet from one of the sides was dissected. From fish captured in the NCC, except from the Skagerrak coast and two of the localities near U-864, the liver was also dissected. Liver and muscle samples were separately homogenized, and homogenized muscle tissue was subsequently freeze-dried while liver tissue was analyzed wet.

\subsection{Analysis}

The mercury determination was performed using multielement inductive coupled plasma mass spectrometry (ICPMS) after microwave-assisted wet digestion of the samples, according to the method described by Julshamn et al. [19].

About $0.2 \mathrm{~g}$ of muscle, and $0.5 \mathrm{~g}$ of liver were separately weighed. A volume of $2 \mathrm{~mL} \mathrm{HNO}_{3}$ (69\% Suprapur) and $0.5 \mathrm{~mL} \mathrm{H}_{2} \mathrm{O}_{2}$ (30\% p.a. ISO) were added to the biological material. The test solution was then placed in a MILESTONE microwave oven (MILESTONE Microwave digestion system MLS-1200 MEGA Microwave Digestion Rotor (MDR 300/10)) for wet digestion (250 W, 1 min; 0 W, 1 min; $250 \mathrm{~W}, 5 \mathrm{~min} ; 400 \mathrm{~W}, 5 \mathrm{~min} ; 650 \mathrm{~W}, 5 \mathrm{~min})$. The test solutions were subsequently diluted to $25 \mathrm{~mL}$ with 
water (MILLI-Q). All the samples and SRM were analyzed using an ICPMS (Agilent 7500c), (ICP-ChemStation software). The precision and trueness of the measurements were obtained by using standard reference materials (SRM): Tort-2 (National Research Council, NRC, Canada) and oyster tissue (OT, CRM 1566, National Institute of Standards \& Technology, NIST). The SRM was prepared and analyzed in the same way as the biological material. The results from concomitant analysis of samples and SRM were found to be satisfactory. The method is accredited by the Norwegian Accreditation Authority after ISO 17025.

\subsection{Statistics and Calculations}

The statistical analyses and calculations were carried out using Statistica 9.0 [20] and Microsoft Office Excel 2007. One-way analysis of variance (ANOVA) was applied to test for differences among the different localities. To obtain homogeneity of the variances between the different groups, some of the parameters were $\log$ transformed prior the statistical analyses. When ANOVA showed that there were significant differences, Tukey HSD post hoc was used to investigate which localities differed from each other.

Variance components analysis with nested ANOVA was applied to investigate whether there were significant differences between different larger areas (NCC, U-864, fjords, Southern sea $\left(<62{ }^{\circ} \mathrm{N}\right)$ and Northern $\left(>62^{\circ} \mathrm{N}\right)$ sea that was not just due to differences between localities).

Linear correlation was applied to test for any significant correlation between mercury concentration and physical parameters (i.e., weight, length and age). A correlation was also made between mean mercury concentration and mean fish weight for each locality.

\subsection{Normalizing the Mercury Concentration by Weight}

Before the statistical comparison between areas, in order to remove the effect of the size of the tusk, the mercury concentrations were normalized by weight using the following Eq. 1:

$$
\mathrm{Hg}_{\text {norm }}=\frac{\mathrm{Hg}(\mathrm{mg} / \mathrm{kg} \mathrm{ww})}{\sqrt{\text { weight of tusk }(\mathrm{g}) / 1000}}
$$

\section{Results}

\subsection{Physical and Biological Parameters}

The weight, length and age of the collected tusk that were analyzed for mercury in muscle are summarized in Table 1. The tusk weighed from 0.4 to $10 \mathrm{~kg}$, with an overall mean weight of $2.1 \mathrm{~kg}$. The size of the tusk varied considerably between the different localities. The smallest fish were caught at the three localities near U-864, with mean weights between 0.8 and $1.1 \mathrm{~kg}$, and the tusk fished from all these three localities were significantly $(P<0.05)$ smaller than those from the other NCC localities, where mean weights varied from about 2.1 to $2.9 \mathrm{~kg}$. The largest fish were those caught in the Hardangerfjord, with a mean weight of $5.0 \mathrm{~kg}$, and these fish were significantly heavier than those collected in the NCC area. Of the tusk collected in the open ocean, those caught at the localities NW2 and BS1 were the smallest, both with mean weights of only $1.1 \mathrm{~kg}$, while the largest fish were caught in the North Sea, which had a mean weight of $4.4 \mathrm{~kg}$. Those captured in the North Sea were significantly larger, both in weight and length, compared to the rest of the tusk captured in the open ocean $(P<0.001)$.

Age was only determined in tusk captured in the NCC and in Hardangerfjord, excluding the localities near U-864 and Skagerrak coast. Among these, mean age varied from 9 to 10 years, while age of individual fish varied from 4 to 15 years. Of the localities analyzed for age, there were no significant differences between the tusk collected in the different areas.

\subsection{Mercury Concentrations Determined in Muscle}

Mercury concentrations found in the muscle of tusk collected at all the different localities are given in Table 2. Concentrations in individual fish varied from 0.04 to $3.6 \mathrm{mg} \mathrm{kg}^{-1} \mathrm{ww}$. The mean concentrations for the 
Distribution of Mercury in a Gadoid Fish Species, Tusk (Brosme brosme), and Its Implication for Food Safety

Table 1 Weight, length, and age for tusk collected from the Norwegian coastal current and in the fjords. Means, min and max are shown for the physical parameters.

\begin{tabular}{lllllll}
\hline Locality & Sampling month and year & $N$ & Weight (g) & Length (cm) & $N$ aged & Age \\
\hline Sørfjord & October 2008 & 11 & $3,364 *$ & - & - & - \\
Hardangerfjord & December 2009 & 25 & $5,044(1,864-9,972)$ & $74(56-95)$ & 15 & $10(4-15)$ \\
Karmøy & November 2009 & 15 & $2,113(1,580-2,980)$ & $59(53-67)$ & 14 & $9(4-13)$ \\
Sotra & October 2009 & 25 & $2,094(980-4,900)$ & $57(44-74)$ & 23 & $10(6-15)$ \\
4 nm South of U-864 & October-November 2009 & 25 & $897(480-1,620)$ & $55(36-57)$ & - & - \\
U-864 & July 2009 & 25 & $931(380-2,640)$ & $43(35-62)$ & - & - \\
4 nm North of U-864 & July 2009 & 25 & $1,036(420-1,900)$ & $46(33-57)$ & - & - \\
Florø & November 2009 & 22 & $2,678(1,600-6,200)$ & $60(52-75)$ & 19 & $9(4-13)$ \\
Breisundet & April-May 2009 & 26 & $2,889(800-8,600)$ & $61(42-90)$ & 25 & $9(5-14)$ \\
Skagerrak & December 2008 & 45 & & & & - \\
Atlantic Ocean 1 & July 2008 & 25 & $1,936(920-3,460)$ & $57(44-69)$ & - & - \\
Atlantic Ocean 2 & March 2008 & 25 & $1,338(480-2,220)$ & $50(37-69)$ & - & - \\
North Sea & September 2008 & 15 & $4,444(1,000-5,740)$ & $73(47-81)$ & - & - \\
Norwegian Sea 1 & May 2008 & 24 & $1,387(580-2,740)$ & $49(38-61)$ & - & - \\
Norwegian Sea 2 & September 2008 & 25 & $1,096(460-2,100)$ & $46(37-56)$ & - & - \\
Barents Sea 1 & June 2008 & 25 & $1,130(580-1,820)$ & $46(38-54)$ & - & - \\
Barents Sea 2 & October 2008 & 25 & $1,699(720-4,080)$ & $52(41-68)$ & - & - \\
\hline
\end{tabular}

* Individual weight of tusk from Sørfjord was not recorded, and only the mean weight is presented here.

Table 2 Concentrations of mercury in muscle and liver of tusk from all sampling sites. Means \pm standard deviation, min and max are shown.

\begin{tabular}{llll}
\hline & $N$ & \multicolumn{1}{c}{ Concentration of mercury (mg/kg ww) } \\
\cline { 3 - 4 } Sørfjord & 11 & $1.7 \pm 1.0(0.55-3.6)$ & Liver \\
Hardangerfjord & 25 & $1.5 \pm 0.5(0.68-2.6)$ & $4.3 \pm 10(0.66-37)$ \\
Karmøy & 15 & $0.49 \pm 0.18(0.29-1.0)$ & $0.35 \pm 0.27(0.08-1.2)$ \\
Sotra & 25 & $0.48 \pm 0.23(0.19-1.10)$ & $0.51 \pm 0.63(0.10-3.2)$ \\
4 nm south of U-864 & 25 & $0.22 \pm 0.09(0.10-0.53)$ & - \\
Fedje (U-864) & 25 & $0.21 \pm 0.08(0.11-0.41)$ & - \\
4 nm north of U-864 & 25 & $0.35 \pm 0.08(0.21-0.54)$ & $0.27 \pm 0.27(0.05-1.2)$ \\
Florø & 22 & $0.37 \pm 0.17(0.19-0.88)$ & $-17 \pm 0.24(0.05-1.3)$ \\
Breisundet & 26 & $0.21 \pm 0.08(0.09-0.43)$ & - \\
Skagerrak & 45 & $0.44 \pm 0.19(0.15-1.00)$ & - \\
\hline Atlantic Ocean 1 & 25 & $0.23 \pm 0.14(0.08-0.50)$ & - \\
Atlantic Ocean 2 & 25 & $0.13 \pm 0.05(0.06-0.22)$ & - \\
North Sea & 15 & $0.30 \pm 0.11(0.11-0.54)$ & - \\
Norwegian Sea 1 & 24 & $0.15 \pm 0.03(0.09-0.20)$ & - \\
Norwegian Sea 2 & 25 & $0.11 \pm 0.02(0.08-0.16)$ & - \\
Barents Sea 1 & 25 & $0.12 \pm 0.05(0.06-0.35)$ & \\
Barents Sea 2 & 25 & $0.08 \pm 0.03(0.04-0.12)$ &
\end{tabular}

localities varied between 0.08 and $1.7 \mathrm{mg} \mathrm{kg}^{-1}$ ww. The lowest mercury concentrations were found at the Northernmost open ocean locality, BS2, and the highest in the innermost fjord locality, Sørfjord. All the individual tusk from the Hardangerfjord and Sørfjord had mercury concentrations in muscle exceeding the EU's upper limit of $0.5 \mathrm{mg} \mathrm{kg}^{-1} \mathrm{ww}$, and the mean mercury concentrations were more than three times higher than EU's upper limit, with concentrations of 1.5 and $1.7 \mathrm{mg} \mathrm{kg}^{-1} \mathrm{ww}$, respectively. 
Among the NCC localities, tusk from Sotra, Karmøy and Skagerrak coast had mean concentrations of mercury close to the EU's upper limit of $0.5 \mathrm{mg} \mathrm{kg}^{-1}$ ww, with $0.48,0.49$ and $0.44 \mathrm{mg} \mathrm{kg}^{-1} \mathrm{ww}$, respectively. The lowest mercury levels among the localities in the NCC were at the U-864 and Breisundet, both with mean concentrations of $0.21 \mathrm{mg} \mathrm{kg}^{-1}$ ww. From all of the sampling localities along the NCC and the fjords, except Breisundet and U-864, individuals of tusk were collected that contained a mercury concentration exceeding the EU's upper limit.

The highest mean mercury concentration found in muscle of tusk collected from open ocean localities was $0.30 \mathrm{mg} \mathrm{kg}^{-1} \mathrm{ww}$ in tusk from the North Sea.

There was a significantly positive correlation between the concentration of mercury and fish weight when all fish from all positions were combined $(P<$ $0.001, r^{2}=0.44$, Fig. 2). When mean mercury concentrations in tusk for each of the localities were plotted against mean fish size at the localities, Hardangerfjord and Sørfjord stations had mercury concentrations that were high relative to the fish size (Fig. 3). Tusk from the North Sea on the other hand had a low concentration of mercury relative to the fish size.

In order to remove the effect of size when comparing the different localities, the concentrations of mercury were normalized by weight (Eq. 1). After weight normalization, the concentrations were no longer positively correlated with fish weight, and a more proper comparison between areas and localities could be made. As a result of the lack of individual weight data of the tusk from the Sørfjord, the mercury concentrations in the muscle of tusk from this locality could not be normalized.

When concentrations of mercury in muscle of tusk from the NCC were normalized by weight, the mercury concentrations were more similar between the localities (Fig. 4). Excluding the tusk collected $4 \mathrm{~nm}$ North of U-864, which had the highest weight normalized mercury concentration, mercury concentrations now seemed to decrease Northwards

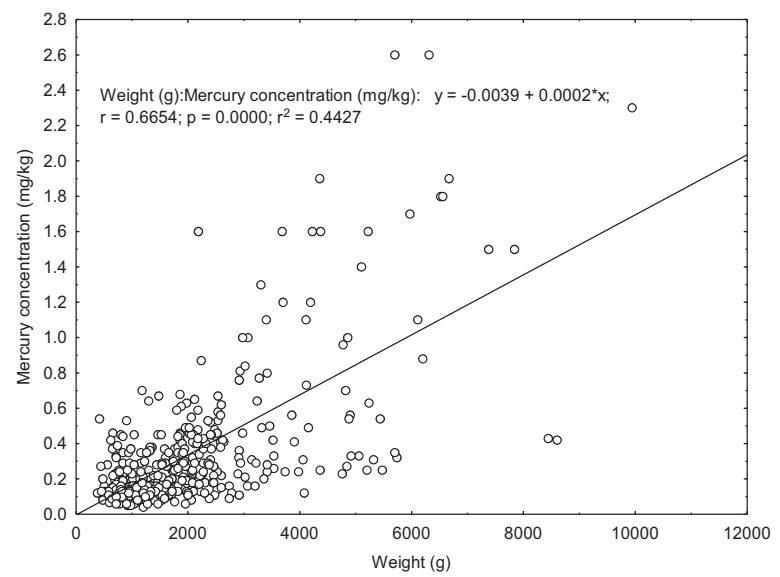

Fig. 2 Tusk (Brosme brosme) sampled in different areas in Norwegian waters. Correlation between the concentration of mercury ( $\mathrm{mg} / \mathrm{kg} \mathrm{ww})$ in muscle of tusk against fish weight (g). As a result of the lack of individual weight of the tusk collected from Sørfjord, tusk from this locality are not included.

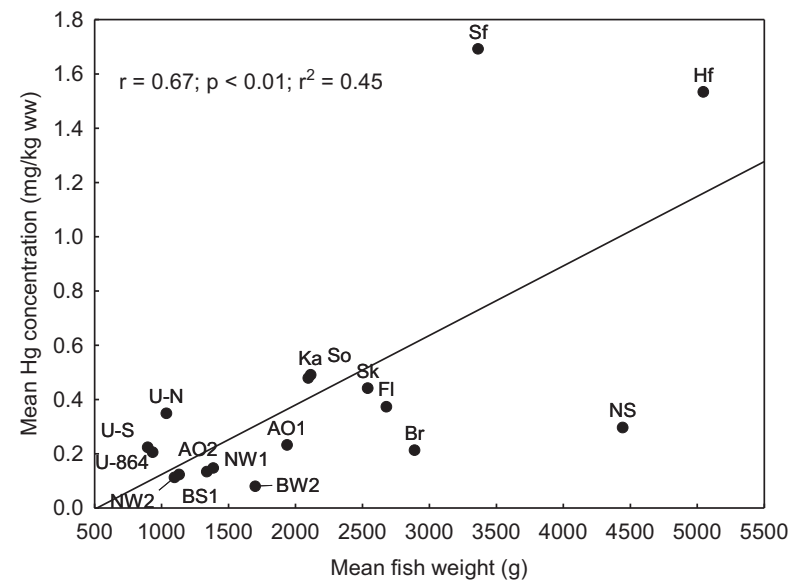

Fig. 3 Correlation between mean mercury concentration ( $\mathrm{mg} / \mathrm{kg} \mathrm{ww}$ ) and mean fish weight (g) of tusk (Brosme brosme) captured in different localities: AO: Atlantic Ocean, NS: North Sea; NW: Norwegian Sea; BS: Barents Sea; Sk: Skagerrak coast, Ka: Karmøy; So: Sotra; Fl: Florø; Br: Breisundet; U: U-864; U-S: 4 nautical miles (nm) south of U-864; U-N; $4 \mathrm{~nm}$ north of U-864; Hf: Inner Hardangerfjord; Sf: Sørfjord.

from Karmøy to Breisundet. Tusk from Karmøy and Sotra had significantly higher weight normalized mercury concentrations than tusk from Florø and Breisundet as well as tusk captured at U-864 and $4 \mathrm{~nm}$ South of U-864. Tusk from Breisundet also had significantly lower mercury concentrations than tusk from all other localities. 


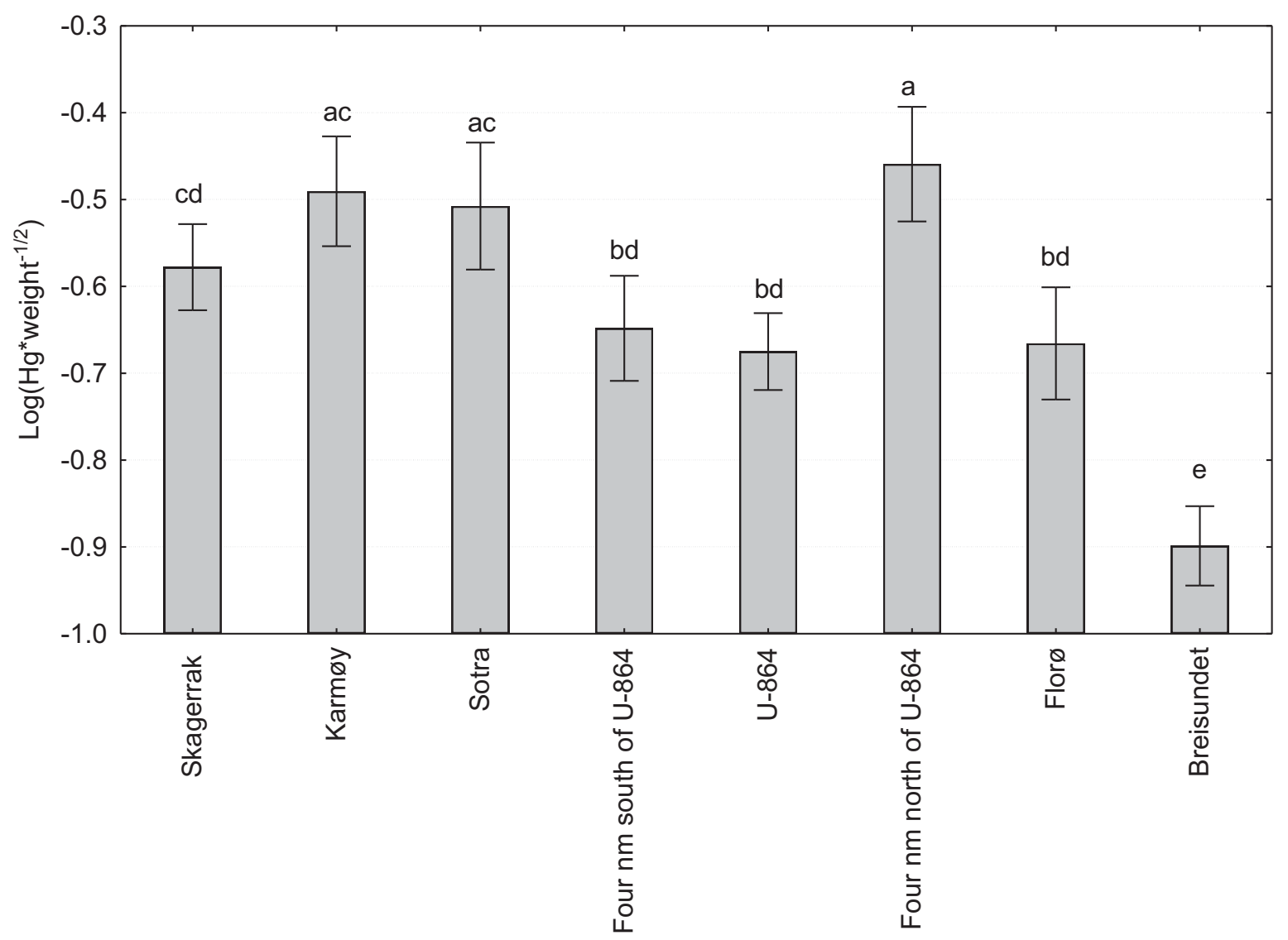

Fig. 4 Mean weight normalized mercury concentrations in tusk (Brosme brosme) captured in different localities along the NCC. Means and $95 \%$ confident intervals are shown for each group. The data are log-transformed. Different letters above columns indicate significant differences $(P<0.05)$.

Also for the tusk from the open ocean, there was a tendency of decreasing weight normalized mercury concentration from South to North (Fig. 5). The tusk collected from the most Northern locality (BS2) showed significantly lower weight normalized concentrations of mercury compared to tusk collected from the other open ocean areas, and tusk from the most Southern locality (AO1) showed significantly higher weight normalized concentrations compared with tusk from the three Northernmost localities, NW2, BS1 and BS2. Due to the large size of the tusk caught in the North Sea, the weight normalized concentrations of mercury from this locality were within the normal range for concentrations found in tusk from the open ocean areas, even if the non-normalized mercury concentrations were higher (Table 2).

Variance components analysis with hierarchically nested design, where the factor locality was nested within the factor area, showed that both area and locality had significant effects on the variance of weight normalized mercury concentrations in tusk muscle. Comparing the areas (fjords, NCC, U-864, Southern sea and Northern sea) with one-way ANOVA, showed that there was no significant difference between tusk collected from the coast and the localities around U-864. Between all other areas, there were significant differences in weight normalized mercury concentration. The mean mercury concentrations were the highest in tusk from the fjords and the lowest in tusk from the Northern sea (Fig. 6).

\subsection{Ratio of Mercury Concentrations in Liver and Muscle}

The mercury concentrations in the tusk livers sampled in the NCC and the fjords varied from 0.02 to 


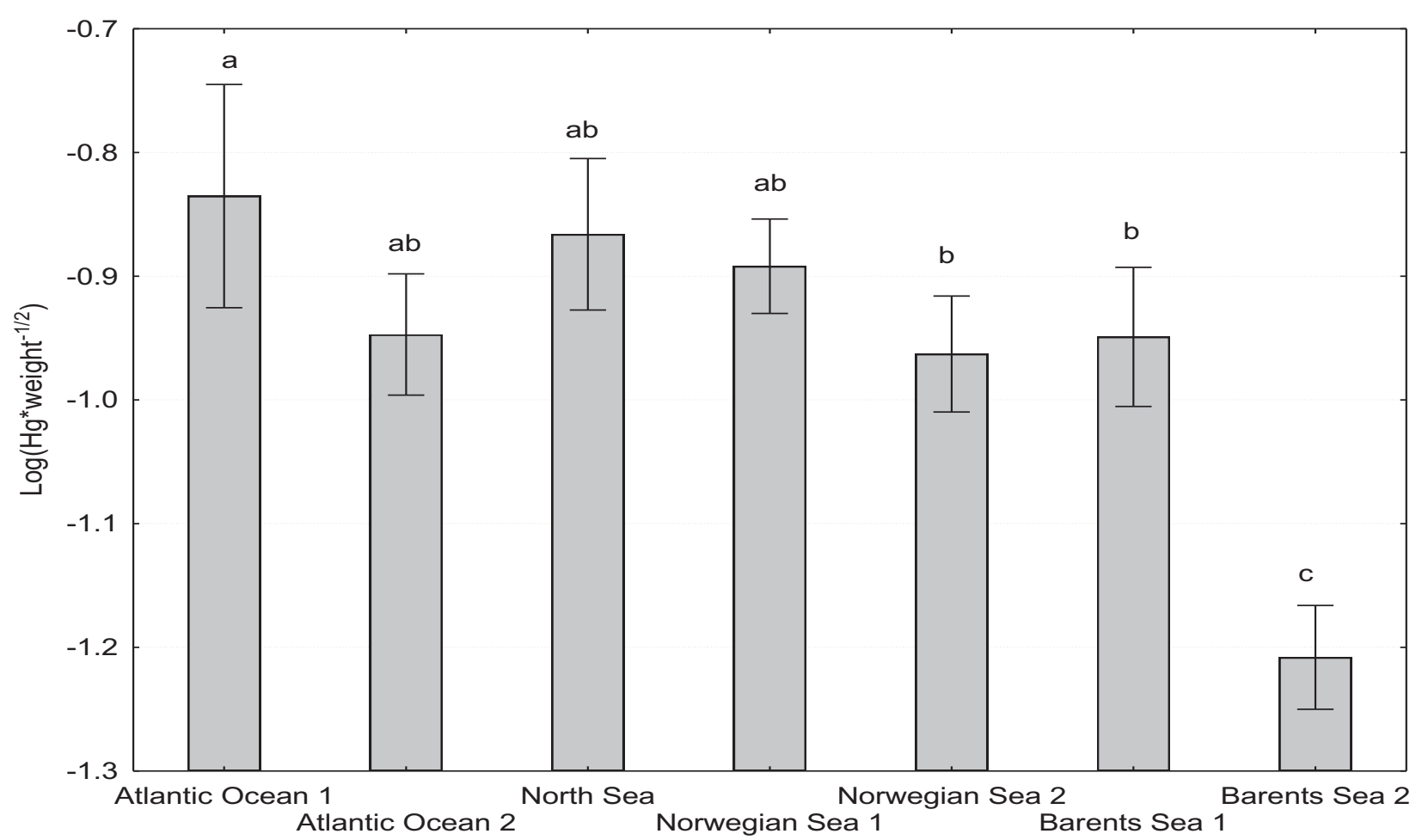

Fig. 5 Mean weight normalized mercury concentrations in tusk (Brosme brosme) captured in different ocean open localities. Means and $95 \%$ confident intervals are shown for each group. The data are log-transformed. Different letters above columns indicate significant differences $(P<0.05)$.

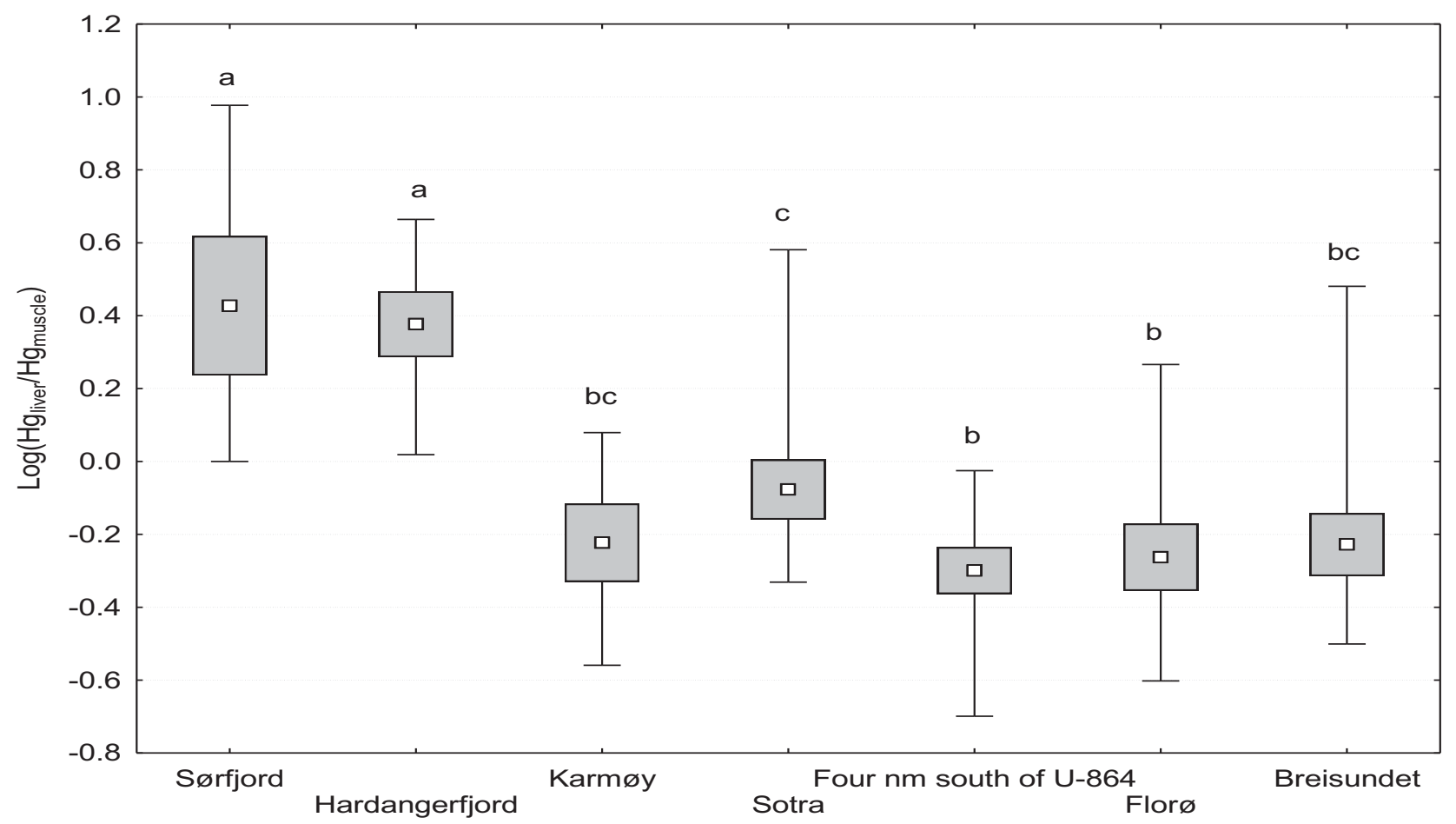

Fig. 6 Ratio of mercury concentration in liver and muscle of tusk (Brosme brosme) captured in different localities in Norway. Means, 95\% confidence intervals, min and max values of $\log$ transformed data are shown. Different letters above columns indicate significant differences $(P<0.05)$. 


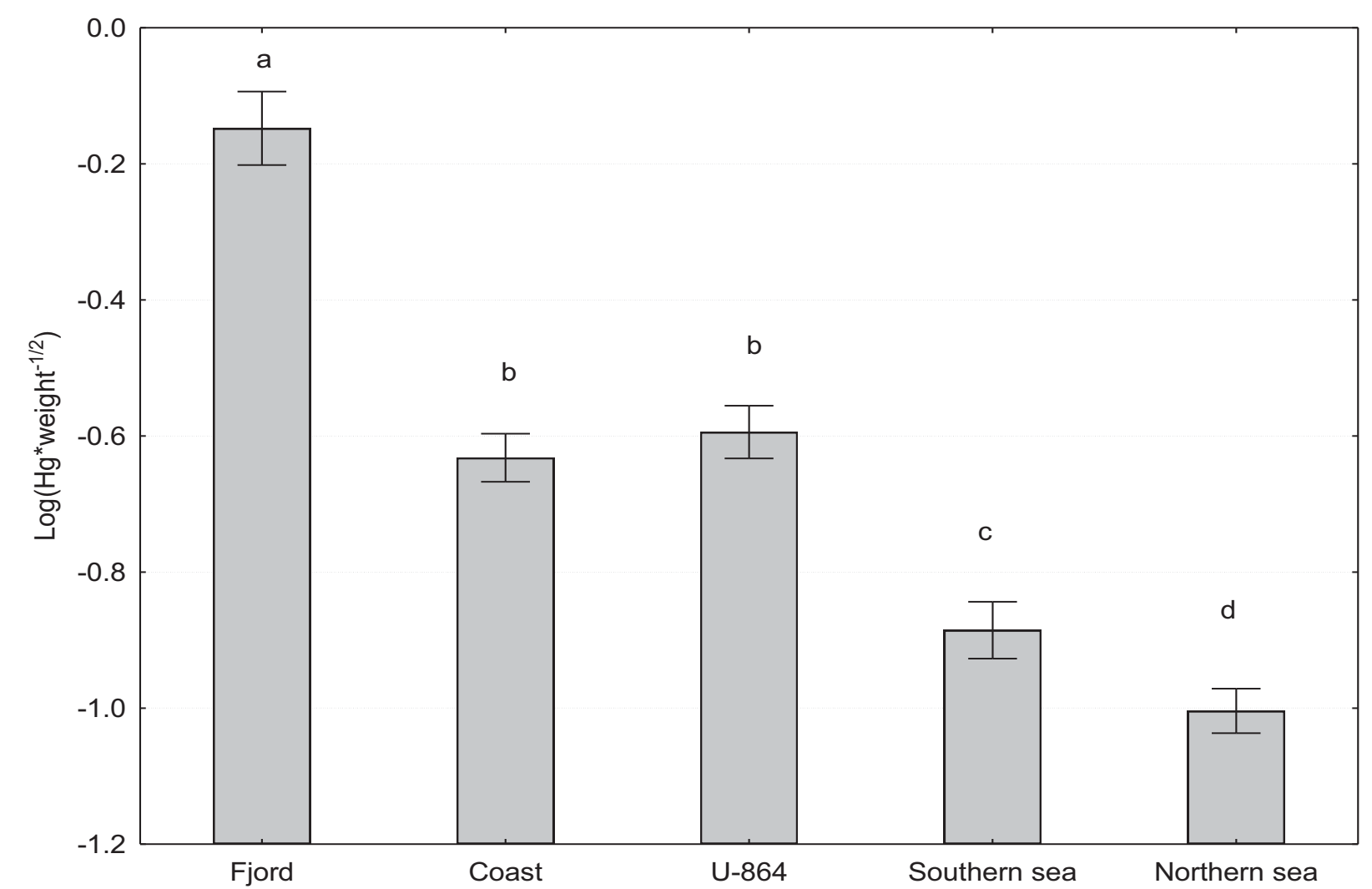

Fig. 7 Mercury concentration in muscle of tusk (Brosme brosme) captured in different areas in Norwegian waters. Means \pm 95\% confidence intervals are shown. Different letters above columns indicate significant differences $(P<0.05)$.

$37 \mathrm{mg} \mathrm{kg}^{-1}$, and mean concentrations for the different localities varied from $0.13 \mathrm{mg} \mathrm{kg}^{-1}$ at $4 \mathrm{~nm}$ South of U-864 to $7.3 \mathrm{mg} \mathrm{kg}^{-1}$ in Sørfjord (Table 2). The ratio between mercury concentrations in liver and muscle $\mathrm{Hg}_{\text {liver }} / \mathrm{Hg}_{\text {muscle }}$ was calculated, and the results are given in Fig. 7. It shows that tusk collected from the fjord localities, Sørfjord and Hardangerfjord, had a significant higher $\mathrm{Hg}_{\text {liver }} / \mathrm{Hg}_{\text {muscle }}$ compared to the NCC tusk, with ratios of 3.3 and 2.7, respectively. Tusk collected at the locality outside Sotra had a higher average $H g_{\text {liver }} / \mathrm{Hg}_{\text {muscle }}$ than the rest of the NCC localities. The ratio was significantly higher than tusk collected 4 nm South of U-864 and Florø.

\section{Discussion}

4.1 Geographical Variation in Tusk from the Different Areas

A comparison of mercury concentrations in tusk from different geographic regions, open ocean South and North of $62{ }^{\circ} \mathrm{N}$, along the Norwegian coastal current and the fjords, showed that mercury levels were the highest in the fjords, lowest in the Northernmost open ocean and intermediate in the Southern open ocean and at the coast. Along with decreasing concentrations from South to North both in open ocean and at the coast, this clearly indicates that although mercury can be transported long distances from the point of discharge, the levels in fish seem to be the highest the closer one gets to densely populated urban areas.

It was a clear pattern that mean mercury concentration in tusk from the open ocean showed a gradually decreasing trend from the most Southern sampling sites in the Atlantic Ocean with $0.23 \mathrm{mg} \mathrm{kg}^{-1}$ ww to the Northernmost site in the Barents Sea with $0.08 \mathrm{mg} \mathrm{kg}^{-1} \mathrm{ww}$.

The highest mean concentration in tusk captured in open ocean was found in the North Sea with a mean concentration of $0.30 \mathrm{mg} \mathrm{kg}^{-1} \mathrm{ww}$, but these fish were 
relatively large, and when mercury concentrations were weight normalized, the values were in the same range as fish from other open ocean areas.

Along the coastal current of Western Norway, relatively high mercury concentrations were observed in the South with mean values of $0.44 \mathrm{mg} \mathrm{kg}^{-1}$ ww at the Skagerrak coast and $0.49 \mathrm{mg} \mathrm{kg}^{-1}$ ww outside Karmøy. The mercury concentration decreased northwards along the coast to $0.21 \mathrm{mg} \mathrm{kg}^{-1}$ ww at Breisundet near Ålesund. From all coastal localities except Breisundet and near U-864, individuals of tusk were captured with mercury concentrations in muscle exceeding the upper limit set by the EU of $0.5 \mathrm{mg} \mathrm{kg}^{-1}$ ww. It should also be noted that the mean concentrations of mercury found in muscle of tusk fished at Skagerrak coast, Karmøy and Sotra were close to the EU's upper limit with concentrations at $0.44,0.49$ and $0.48 \mathrm{mg} \mathrm{kg}^{-1} \mathrm{ww}$, respectively.

Data on undesirable substances including mercury in different seafood species from different areas have been collected for NIFES seafood database from 1994 on www.nifes.no/seafooddata. Previously, only two stations of tusk have been included in this database, collected in 1997 and 2005, where 25 and 20 tusk was collected, respectively. Mean concentrations reported were 0.08 and $0.15 \mathrm{mg} \mathrm{kg}^{-1} \mathrm{ww}$, respectively, which was in the lower range of the concentrations found in tusk from the open ocean localities in this study.

Near the Sotra locality, in the area surrounding the city of Bergen, data from a study conducted in 2009 showed tusk collected from the mainland side of the island of Sotra with concentrations of mercury in muscle ranging from 0.17 to $0.50 \mathrm{mg} \mathrm{kg}^{-1} \mathrm{ww}$ (pooled samples, 3-5 individuals) [21], which is in the same range as the tusk sampled in the NCC in this study. The results from the present study showed a relatively high $\mathrm{Hg}_{\text {liver }} / \mathrm{Hg}_{\text {muscle }}$ ratio in tusk from Sotra compared to the other coastal localities, indicating that there may be an anthropogenic pollution source in the area.

The highest mercury concentrations found in this study were in tusk from the two fjord localities. All the individuals of tusk fished from the Sørfjord and the Hardangerfjord had concentrations of mercury in the muscle exceeding the EU's upper limit of $0.5 \mathrm{mg} \mathrm{kg}^{-1}$, and mean concentrations from the two respective localities were 1.7 and $1.5 \mathrm{mg} \mathrm{kg}^{-1} \mathrm{ww}$, i.e., three times higher than the EU's upper limit for legal sale. The data from Sørfjord are consistent with earlier results from investigations from this fjord, showing elevated levels of mercury and other heavy metals caused by industrial pollution [22]. Bottom fish from the Sørfjord is known to be contaminated with mercury [23]. In fact, the level found in our study was rather low compared with data obtained in the year 2000, when concentrations as high as $3.5 \mathrm{mg} \mathrm{kg}^{-1} \mathrm{ww}$ were found [24]. The Sørfjord is an arm in the innermost part of the Hardangerfjord, and the high level of mercury found in tusk captured further out in the Hardangerfjord was less expected as it was believed that this fjord was less affected by the contamination of mercury than the Sørfjord. Also in fjord systems such as the Nordfjord further north with no known sources of mercury, tusk muscle has been found with elevated mercury concentrations compared with ocean samples [25]. This could indicate that there is more bioavailable methyl mercury in the food web pathways in the fjords versus in the open ocean areas.

Tusk collected in the Hardangerfjord and Sørfjord were significantly larger than tusk collected on the coast and in the oceans, and a correlation of mean mercury concentration against mean size showed that this in part explained of the higher mercury concentration. However, also weight-normalized mercury concentrations were significantly higher inside the fjords than in all other areas. Interestingly, there were no significant differences between the age of tusk collected from the Hardangerfjord and in the coastal areas even though they were much larger. It should be noted that it was not possible to determine age for all the fish. The distribution of mercury between the liver and muscle can be used as an indicator of the contamination of mercury in the environment [26], and the result showing that the tusk 
from Hardangerfjord and Sørfjord had the highest $\mathrm{Hg} g_{\text {liver }} / \mathrm{Hg}_{\text {muscle }}$ ratio of all the localities, with ratios of 3.3 and 2.7, is another indication that tusk from these localities are influenced by environmental contamination of mercury.

\subsection{Effect of Size on Mercury Concentration}

The most important physical/biological factor influencing mercury concentration in tusk is size expressed by weight (Fig. 2). This is consistent with results observed in other studies where mercury has been shown to accumulate with weight, length and age [27-32]. This means that larger fish normally contain more mercury than small fish. This increase in mercury by size can have several causes. In general, the rate of elimination is smaller compared to the intake rate [27], leading to increasing mercury concentration with time. Trudel and Rasmussen [33] found that the excretion rate of mercury was negatively correlated with body size. Mercury was eliminated more slowly from larger and older fish. In addition, larger tusk are able to feed on larger prey which may be higher in the food chain [27], and may for this reason contain a higher concentration of mercury. Lower concentrations of mercury in younger tusk can be explained by different feeding in young and adult tusk [34].

\subsection{Evaluation of the Effect of the Submarine Wreck}

The concentrations of mercury were generally lower in tusk captured near the sunken submarine U-864 than in those captured in other coastal current localities. This was probably partly because this fish was relatively small, and when the concentration of mercury was normalized by fish weight, it was found that tusk collected from these three positions contained mercury concentrations within the normal range for mercury found in tusk collected from the coastal current. The station right North of the wreck at this time was slightly higher than the fish at the wreck, and since there is a strong constant Northern current at this depth, this could indicate a slight local effect of the mercury polluted sediments around the wreck.

While adult tusk usually live at deep waters, younger tusk can be found at shallower depths [1]. This can be a possible explanation for the small size of tusk found in this area. Age determinations were not made for the fish captured as a part of the monitoring around U-864, but may be added in our ongoing monitoring.

\subsection{Food Safety}

Our data show relatively high concentrations of mercury in tusk captured close to shore along the coast. In this study, only total mercury has been measured, but observations from earlier studies show that most of the mercury found in the muscle of fish is in its organic form: methyl mercury [9, 35]. Based on the PTWI regarding mercury (1.6 $\mu \mathrm{g} \mathrm{kg}^{-1}$ body weight), a person weight $70 \mathrm{~kg}$ can have a weekly intake of mercury of $112 \mu \mathrm{g}$ without health effects. Consuming $200 \mathrm{~g}$ of tusk fillet from Karmøy with a level of $0.49 \mathrm{mg} \mathrm{Hg} / \mathrm{kg}$ ww gives a mercury intake of $98 \mu \mathrm{g}$, close to a week's tolerable level.

Consuming $200 \mathrm{~g}$ tusk from the Hardangerfjord, a 70 kg person will have an intake of mercury of about 300 $\mu \mathrm{g}$ which is more than twice the PTWI of mercury. The PTWI is based on an overage consuming of mercury over a lifetime. Consuming a meal of $200 \mathrm{~g}$ tusk collected from the Hardangerfjord once a month does not make a risk, assuming other food items contain little mercury.

Based on observations done in studies with freshwater fish, it is not recommended to consume fish over a particular size. The results from this study show that this advice is difficult to apply to tusk since relatively small tusk exceeded the upper limit set by the EU.

The commercial fisheries of tusk is mainly done in the open ocean, with a total capture of about 28,000 tons in the Northeastern Atlantic including the Norwegian coast and Barents Sea [1]. It is not expected that tusk from the open ocean areas will exceed the upper limit of mercury based on the results from this study. However, one should establish a good control 
system for fish from the inner coastal current and the fjords.

\section{Conclusions}

The tusk is distributed over large areas with different habitats. In tusk from the ocean areas relatively low concentrations of mercury were observed, increasing in the coastal current near shore and were rather high in a fjord area with known historical mercury pollution. This puts tusk on the list of species one must follow carefully in order to have knowledge on potential harmful levels of mercury. Relatively high concentrations of mercury were observed in tusk collected from the NCC, with many of the tusk exceeding the EU's upper limit in the Southern parts.

The concentrations of mercury increased with size of tusk, and differences in size of tusk were found between the different sampling sites. The differences seen between sampling sites can thus be explained by the size of the tusk. However, this could not explain the difference in mercury concentrations in tusk collected in the fjords, along the coast and open ocean areas. Tusk fished from the fjords have a significant higher concentration of mercury than tusk fished from both the Norwegian coastal current and the open ocean areas.

Concentration of mercury in tusk from the area around U-864 is low compared to the concentrations found in tusk fished elsewhere from the Norwegian Coastal Current. The reason for the apparently low concentration of mercury observed in tusk fished from U-864 may be linked to the small size of these fish.

Most of the tusk fished from Norwegian vessels was fished from areas where tusk are not assumed to contain a mercury level high enough to give rise to health concerns.

\section{Acknowledgments}

Merete Kvalsund (IMR) is thanked for performing the age determination of the tusk. The authors further would also like to thank the laboratory personnel at
NIFES for help with determining mercury concentrations.

\section{References}

[1] H. Gjøsæter, T. Haug, Ø. Karlsen, J.A. Knutsen, M. Hauge, I. Røttingen, et al., Marine Report 2010: Resources, Environment and Aquaculture in Coastal Areas and Ocean, Havforskningsrapporten 2010: ressurser, miljø og akvakultur på kysten og i havet, Havforskningsinstituttet, In Norwegian, Bergen, 2010, pp. 124-125.

[2] D.M. Cohen, Gadiform fishes of the world: An annotated and illustrated catalogue of cods, hakes, grenadiers and other gadiform fishes known to date, 1990, pp. 29-31.

[3] P. Sandberg, Økonomiske og biologiske nøkkeltal frå dei norske fiskeria, key economic and biological key figures from Norwegian fisheries, 2010.

[4] J. Alexander, Vitenskapskomiteen for mattrygghet, a comprehensive assessment of fish and other seafood in the Norwegian diet, Vitenskapskomiteen for Mattrygghet, Oslo, 2007.

[5] S. Ciardullo, F. Aureli, E. Coni, E. Guandalini, F. Lost, A. Raggi, et al., Bioaccumulation potential of dietary arsenic, cadmium, lead, mercury, and selenium in organs and tissues of rainbow trout (Oncorhyncus mykiss) as a function of fish growth, J. Agric. Food Chem. 56 (2008) 2442-2451.

[6] J.L. Domingo, A. Bocio, G. Falco, J.M. Llobet, Benefits and risks of fish consumption Part I. A quantitative analysis of the intake of omega-3 fatty acids and chemical contaminants, Toxicology 230 (2007) 219-226.

[7] J.G. Dorea, Persistent, bioaccumulative and toxic substances in fish: Human health considerations, Sci. Total Environ. 400 (2008) 93-114.

[8] T.W. Clarkson, The three modern faces of mercury, Environ, Health Perspect 110 (2002) 11-23.

[9] C.J. Cappon, J.C. Smith, Mercury and selenium content and chemical form in fish muscle, Arch. Environ. Contam. Toxicol. 10 (1981) 305-319.

[10] A.F. Castoldi, T. Coccini, S. Ceccatelli, L. Manzo, Neurotoxicity and molecular effects of methylmercury, Brain Res. Bull. 55 (2001) 197-203.

[11] W.F. Fitzgerald, C.H. Lamborg, C.R. Hammerschmidt, Marine biogeochemical cycling of mercury, Chem. Rev. (Washington, DC, US) 107 (2007) 641-662.

[12] C.Y. Chen, N. Serrell, D.C. Evers, B.J. Fleishman, K.F. Lambert, J. Weiss, et al., Meeting report: Methylmercury in marine ecosystems-from sources to seafood consumers, Environ. Health Perspect 116 (2008) 1706-1712.

[13] W. Baeyens, M. Leermakers, T. Papina, A. Saprykin, N. Brion, J. Noyen, et al., Bioconcentration and biomagnification of mercury and methylmercury in North 

and Its Implication for Food Safety

Sea and Scheldt estuary fish, Arch. Environ. Contam. Toxicol. 45 (2003) 498-508.

[14] WHO, Summary and Conclusions of the Sixty-First Meeting of the Joint FAO/WHO Expert Committee on Food Additives (JECFA), JECFA/61/SC, Rome, 10-19 June 2003.

[15] EU, Setting maximum levels for certain contaminants in foodstuffs, Commission Regulation (EC) No 1881/2006, 2006.

[16] S. Frantzen, A. Måge, D. Furevik, K. Julshamn, Mercury content in fish and seafood by the wreck of U864 west of Fedje — New analysis in 2009 and comparison with data from the time period 2004 to 2008, Kvikksølvinnhold i fisk og sjømat ved vraket av U864 vest av Fedje-Nye analyser i 2009 og sammenligning med data fra perioden 2004 til 2008, In Norwegian, 2010.

[17] F. Uriansrud, M. Schanning, A. Ruus, Flux and bioaccumulation of mercury form sediments near sunken German submarine (U864) at Fedje in Hordaland, Utlekking og Bioakkumulering av kvikksølv fra sedimenter nær U864, Fedje i Hordaland. Resultater fra eksperimentelle undersøkelser, NIVA-rapport 5089-2005, In Norwegian, summary in English, 2005, pp. 7-8.

[18] J.A. Berge, M. Schlabach, N.R. Hareide, Identification of brominated flame retardants, chlorinated and bromorganic compounds, mercury and methylmercury in fjords near Aalesund, Norway, Kartlegging av bromerte flammehemmere, klor- og bromorganiske forbindelser, kvikksølv og metylkvikksølv i fjorder nær Ålesund, NIVA, In Norwegian, Oslo, 2007, pp. 68-70.

[19] K. Julshamn, B.E. Grosvik, K. Nedreaas, A. Maage, Mercury concentration in fillets of Greenland halibut (Reinhardtius hippoglossoides) caught in the Barents Sea in January 2006, Sci. Total Environ. 372 (2006) 345-349.

[20] StatSoft Inc, STATISTICA, data analysis software system, 2009.

[21] S. Frantzen, A. Måge, Extended investigation of environmental contaminants used for dietary advice in Bergen Byfjord, Utvidet kostholdsrådsundersøkelse Bergen Byfjord 2009, NIFES, In Norwegian, 2009, pp. 18-20.

[22] A. Ruus, Monitoring the environmental quality in the Sørfjord 2009. Metals in e water, Contaminants in organisms. Overvåking av miljøforholdene i Sørfjorden 2009. Metaller i vannmassene, Miljøgifter i organismer, Norsk institutt for vannforskning, In Norwegian, summary in English, Oslo, 2010, pp. 31-36.

[23] A. Ruus, N.W. Green, Monitoring the environmental quality in the Sørfjord 2006. Contaminants in organisms.Overvåking av miljøforholdene i Sørfjorden 2006, Delrapport 3, Miljøgifter i organismer, Norsk institutt for vannforskning, In Norwegian, summary in
English, Oslo, 2007, pp. 23-24

[24] J. Knutzen, N.W. Green, Monitoring the environmental conditions in Sørfjorden and Hardangerfjorden 2000, Report No. 2. Micropollutants in organisms, including introductory analyses in deep-water fish. Tiltaksorienterte miljøundersøkelser i Sørfjorden og Hardangerfjorden 2000, Delrapport 2, Miljøgifter i organismer med orienterende analyser i dypvannsfisk, In Norwegian, summary in English, Kjeller, 2001, pp. 19-20.

[25] V. Berg, K.I. Ugland, N.R. Hareide, D. Groenningen, J.U. Skaare, Mercury, cadmium, lead, and selenium in fish from a Norwegian fjord and off the coast, the importance of sampling locality, J. Environ. Monit. 2 (2000) 375-377.

[26] M. Havelkova, L. Dusek, D. Nemethova, G. Poleszczuk, Z. Svobodova, Comparison of mercury distribution between liver and muscle: A biomonitoring of fish from lightly and heavily contaminated localities, Sensors 8 (2008) 4095-4109.

[27] E. Gutierrez-Mejia, M.L. Lares, O. Sosa-Nishizaki, Mercury and Arsenic in Muscle and Liver of the Golden Cownose Ray, Rhinoptera steindachneri, Evermann and Jenkins, 1891, from the Upper Gulf of California, Mexico, Bull. Environ. Contam. Toxicol. 83 (2009) 230-234.

[28] S. Mathieson, D.S. McLusky, Interspecies variation of mercury in skeletal-muscle of 5 fish species from inshore waters of the firth of clyde, Scotland, Mar. Pollut. Bull. 30 (1995) 283-286.

[29] D.W. Boening, Ecological effects, transport, and fate of mercury: A general review, Chemosphere 40 (2000) 1335-1351.

[30] N.W. Green, J. Knutzen, Organohalogens and metals in marine fish and mussels and some relationships to biological variables at reference localities in Norway, Mar. Pollut. Bull. 46 (2003) 362-374.

[31] K. Stange, A. Maage, J. Klungsøyr, Contaminants in fish and sediments in the North Atlantic Ocean, Nordic Council of Ministers, Copenhagen, 1996, pp. 34-37.

[32] M.S. Bank, E. Chesney, J.P. Shine, A. Maage, D.B. Senn, Mercury bioaccumulation and trophic transfer in sympatric snapper species from the Gulf of Mexico, Ecological Applications 17 (2007) 2100-2110.

[33] M. Trudel, J.B. Rasmussen, Modeling the elimination of mercury by fish, Environ. Sci. Technol. 31 (1997) 1716-1722.

[34] A.P. de Pinho, J.R.D. Guimaraes, A.S. Martins, P.A.S. Costa, G. Olavo, J. Valentin, Total mercury in muscle tissue of five shark species from Brazilian offshore waters: Effects of feeding habit, sex, and length, Environ. Res. 89 (2002) 250-258.

[35] N.S. Bloom, On the chemical form of mercury in edible fish and marine invertebrate tissue, Can. J. Fish. Aquat. Sci. 49 (1992) 1010-1017. 